GEOLOGY AND SCENERY IN THE LAKE DISTRICT 
Other Macmillan titles of related interest

D. V. Ager, The Nature of the Stratigraphical Record

D. L. Dineley, Aspects of a Stratigraphic System: The Devonian

J. R. Haynes, Foraminifera

C. S. Hutchison, Economic Deposits and their Tectonic Setting

F. Moseley, The Volcanic Rocks of the Lake District

H. H. Read and Janet Wilson, Introduction to Geology:

Volume 1 Principles

Volume 2 Earth History,

Part 1: Early Stages of Earth History

Volume 2 Earth History,

Part 2: Later Stages of Earth History 


\title{
Geology and Scenery in the Lake District
}

\author{
F. MOSELEY \\ Reader in Geology, \\ Department of Geological Sciences, \\ University of Birmingham
}

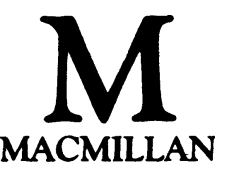


All rights reserved. No reproduction, copy or transmission of this publication may be made without written permission.

No paragraph of this publication may be reproduced, copied or transmitted save with written permission or in accordance with the provisions of the Copyright Act 1956 (as amended).

Any person who does any unauthorised act in relation to this publication may be liable to criminal prosecution and civil claims for damages.

First published 1986

\section{Published by}

MACMILLAN EDUCATION LTD

Houndmills, Basingstoke, Hampshire RG21 2XS

and London

Companies and representatives

throughout the world

Typeset by TecSet Ltd,

Sutton, Surrey

British Library Cataloguing in Publication Data

Moseley, F.

Geology and scenery in the Lake District.

1. Geology-England-Lake District

I. Title

554.27'8

QE262.L2

ISBN 978-0-333-41781-2 ISBN 978-1-349-08762-4 (eBook)

DOI 10.1007/978-1-349-08762-4 


\section{Contents}

\section{Preface}

1. Introduction

2. The Skiddaw Slates of Whiteside, Gasgale and Grasmoor

3. Glacial and Solid Geology of the Buttermere Area

4. The Borrowdale Volcanics of Fleetwith Pike and Honister

5. Styhead to Allen Crags

6. Pike o'Blisco, Langdale

7. The Band to Bowfell

8. Helm Crag, Grasmere

9. Dove Crag

10. Fairfield

11. Tarn Hows and the Coniston Limestone

12. The Brathay Flags of Banishead, Coniston

13. The Bannisdale Slates of Blawith Common and Beacon Tarn

14. The Coniston Grits and Bannisdale Slates of Shap

15. Whitbarrow and the Carboniferous Limestone

16. Conclusion

Index 


\section{Preface}

This book follows on from The Volcanic Rocks of the Lake District (Moseley, 1983a) in which the environment of the 450 million year old 'Borrowdale Volcano' was described, and a number of field excursions detailed. It is, like the first book, mostly concerned with the volcanic rocks which form the central core of Lakeland, but it also includes sections on the older Skiddaw Slates and the younger Silurian and Carboniferous rocks. The method adopted has been to use numerous illustrations, the written sections being kept to a minimum. I hope the book will prove to be understandable to amateur geologists and to those just beginning to study the subject; nevertheless, there should be sufficient information for professionals not familiar with the Lake District and for those wishing to lead University parties across the ground.

Although the two books together contain 30 excursion guides and recommendations, they by no means exhaust the possibilities for the Lake District. These guides deal only with the areas I know best, and important and popular regions such as Scafell, Skiddaw and Haweswater have not yet been covered.

\section{Note on maps}

Maps given in this book show the general route of each excursion. It is recommended that these be supplemented by the appropriate walkers' maps for the area. The whole of the Lake District is covered by an Ordnance Survey 1:50000 (about $1 \frac{1}{4}$ inches to 1 mile) Tourist Map. Even better are the 1:25000 (about $2 \frac{1}{2}$ inches to 1 mile) Ordnance Survey series. The relevant maps are noted at the beginning of each excursion. Four 'Outdoor Leisure' maps are also available which cover the whole of the Lake District at a scale of 1:25000. All these maps are obtainable from local Ordnance Survey stockists. 